International Journal of Computer and Information System (IJCIS)

Peer Reviewed - International Journal

Vol : Vol. 03, Issue 01, January 2022

e-ISSN : 2745-9659

https://ijcis.net/index.php/ijcis/index

\title{
Selection Index (PSI) Method in Developing a Student Scholarship Decision Support System
}

\author{
$1^{\text {st }}$ Nur Arifin, $2^{\text {nd }}$ Pujo Hari Saputro \\ ${ }^{1,2}$ Informatika, Computer and Teknik \\ Universitas Alma Ata \\ Yogyakarta, Indonesia \\ ${ }^{1} 173200012 @$ almaata.ac.id, ${ }^{2}$ pujo@almaata.ac.id
}

\begin{abstract}
Scholarships are the provision of financial assistance for students or students with the aim that these students can continue their education that is being achieved. Decision Support System (DSS) is a system that can provide a problem or a communication capability for problems in unstructured and semi-structured conditions. The Preference Selection Index (PSI) method was developed by Maniya Bhatt (2010) to solve multiple decision criteria (MCDM). In the proposed method of weighting it is not necessary to assign relative importance between attributes, in fact, there is no need for attributes involved in decision making in this method. Compared to other MCDM methods, the PSI method is easier to reach because it involves fewer numerical calculations The best alternative generation results were obtained by Aldea Mulia Sinai with a value of 0.7712.
\end{abstract}

Keywords : Scholarship, Decision Support System, Preference Selection Index (PSI) Method

\section{INTRODUCTION}

Education is one of the basic formations and as a supporting factor for quality human resources. However, the cost of getting an education is an obstacle for people with middle to lower economics, especially at the college level which requires quite a large amount of money. So some universities provide scholarships for underprivileged students. Scholarships are the provision of financial assistance to students or students with the aim that these students can continue their education. According to Murniasih (2009) scholarships can be interpreted as a form of award given to students so that they can continue their studies at a higher level[1].

Scholarships must be awarded to students who are appropriate and deserving of the scholarship. With the provisions and criteria provided by the scholarship selection field and the limited number of scholarships awarded each period, in conducting the scholarship selection [2]. So with this decision support system was made in order to help selectors in the process of producing the right decision alternatives. The support system is a system that is able to provide results in problem solving based on various predetermined criteria and can assist students in submitting scholarship requirements without having to come directly to the university.

So with this decision support system was made in order to help selectors in the process of producing the right decision alternatives. The support system is a system that is able to provide results in problem solving based on various predetermined criteria and can assist students in submitting scholarship requirements without having to come directly to the university[3].

The model used in the research in making this decision support system is the Multi-Criteria Decision Making (MCDM) model. Preferences Selection Index (PSI) is a decision support system method that is rarely used. This method is a method developed by stevanie and Bhatt (2010) to solve Multi Criteria Decision Making (MCDM)[4]. In its application, this system uses a method to analyze decision making. The author uses the Preference Selection Index (PSI) method in the application of decision making. The Preference
Selection Index (PSI) method is a method for choosing the best alternative from a given alternative without deciding the relative importance between attributes [5].

In its application, this system uses a method to analyze decision making. The author uses the Preference Selection Index (PSI) method in the application of decision making. The Preference Selection Index (PSI) method is a method for choosing the best alternative from a given alternative without deciding the relative importance between attributes[4]. The international journal conducted by Rajesh Atrri and Sandeep, entitled Application of preference selection index method for decision making over the design stage of the production system life cycle, concluded that the PSI method is the most appropriate and competent for decision-making problems that have many interrelated attributes. contradictory. Compared to other MCDM methods, the PSI method is easier to understand because it involves less numerical calculations[6]. The international journal conducted by Rajesh Atrri and Sandeep, entitled Application of preference selection index method for decision making over the design stage of the production system life cycle, concluded that the PSI method is the most appropriate and competent for decision-making problems that have many interrelated attributes. contradictory. Compared to other MCDM methods, the PSI method is easier to understand because it involves less numerical calculations[4].

The author uses the Preferences Selection Index (PSI) method to produce decision support for student scholarship acceptance, this method is used to rank the data of prospective scholarship recipients with predetermined criteria. The application of the method also aims to determine whether the PSI method provides good decisions in providing rankings for supporting student scholarship acceptance decisions.

\section{RESEARCH METHODS}

The basic method used in this research is descriptive analysis. Descriptive according to Sugiyono (2009) is a method that functions to describe the object to be studied through data that has been collected as it is without analyzing and making generally accepted conclusions[7]. The basic 
International Journal of Computer and Information System (IJCIS)

Peer Reviewed - International Journal

Vol : Vol. 03, Issue 01, January 2022

e-ISSN : 2745-9659

https://ijcis.net/index.php/ijcis/index

method used in this research is descriptive analysis. Descriptive according to Sugiyono (2009) is a method that functions to describe the object to be studied through data that has been collected as it is without analyzing and making generally accepted conclusions.

\subsection{Research sites}

This research will be conducted at Alma Ata University, Yogyakarta.

\subsection{Data Types and Sources}

In this study, two types of data sources are used, namely:

1. Primary data is data obtained directly from the source. The data was obtained from the Alma Ata scholarship field.

2. Secondary data is the opposite of primary, which is obtained indirectly from literature, documents, journals, or web sites or books related to this research.

\subsection{Method of collecting data}

The data collection methods used in this study are as follows:

1. Interview Method

The interview process is by way of question and answer with Alma Ata's staff to ask for data related to scholarships.

\section{Library Method}

This method collects data from several literature sources such as books, journals, websites, and other sources of information related to the problem under study.

\subsection{System Development Method}

At this stage, the system uses the waterfall method. Waterfall is one of the methods for the creation or development of systems or soft wars that are made in succession like waterfalls. There are several stages of the waterfall: analysis, design, implementation, testing and maintenance[8].

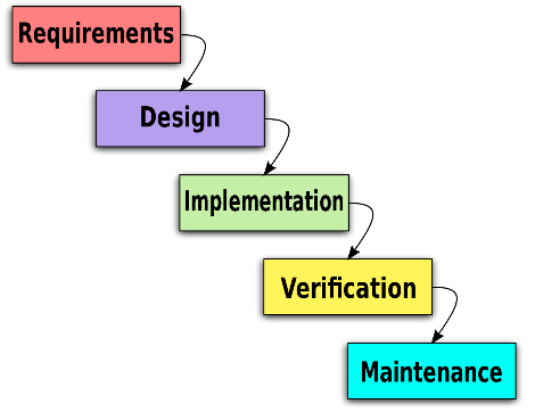

Figure 1 Waterfall

- Requirements gathering and analysis, namely collecting complete requirements and then analyzing and defining the requirements that must be met by the system to be created. In this stage it must be done completely so that the foam produces a design.

- Design is the stage of producing a system design as a whole and determining the flow of the system.

- Implementation is the stage where all designs that have been made are converted into coding. Making the system is divided into small modules that will be combined in the next stage.

- Integration and testing are all systems that have been made in the previous stages and then tested to check for any errors or system failures.

- Operation and Maintenance, that is, the system that has been made may one day have an update or an error occurs or the system is developed again.

\section{RESULT AND ANALYSIS}

\subsection{PSI Method Algorithm Implementation}

Making a decision support system (DSS) using the Preferences Index Selection (PSI) method The term DSS refers to a system that utilizes computer support in the decision-making process, the following are the opinions of experts on the meaning of DSS (Decision Support System) is a system that can help make decisions through the use of data and decision models to solve semi-structured and unstructured problems. In making SPK using the PSI method requires criteria that will be taken into consideration and calculations. The criteria obtained[9].

Tabel 1. Criteria

\begin{tabular}{ccl}
\hline No & Criteria & \multicolumn{1}{c}{ Keterangan } \\
\hline 1 & C1 & Parent's Income (cost) \\
2 & C2 & The number of dependents \\
3 & C3 & Parents' job \\
4 & C4 & Achievement \\
\hline
\end{tabular}

In the consideration and calculation of PSI also requires the preference value and the weight value of each criterion.

Tabel 2 Weight value

\begin{tabular}{cll}
\hline No & Category & Weight value \\
\hline 1 & Very high & 5 \\
2 & Hight & 4 \\
3 & Enough & 3 \\
4 & Low & 2 \\
\hline
\end{tabular}

Tabel 3. Parent's income

\begin{tabular}{llc}
\hline Category & parent's income & Weight value \\
\hline Very Hight & $<500.000$ & 5 \\
Hight & $500000-<1.000 .000$ & 4 \\
Enough & $1000.000-<1800.000$ & 3 \\
Low & $1800.000-2500.000$ & 2 \\
Very Loq & $2500.000>$ & 1 \\
\hline
\end{tabular}

Tabel 4 Dependent

\begin{tabular}{lc}
\hline Dependent Category & Wight Value \\
\hline More $>3$ & 5 \\
3 & 4 \\
2 & 3 \\
1 & 2 \\
blank & 1 \\
\hline
\end{tabular}


International Journal of Computer and Information System (IJCIS)

Peer Reviewed - International Journal

Vol : Vol. 03, Issue 01, January 2022

e-ISSN : 2745-9659

https://ijcis.net/index.php/ijcis/index

Tabel 5. Work

\begin{tabular}{lc}
\hline Work & Job value \\
\hline PNS & 4 \\
private & 3 \\
farmer & 2 \\
not fixed & 1 \\
\hline
\end{tabular}

Tabel 6. Achievement

\begin{tabular}{lc} 
achievement & nilai bobot \\
\hline Has 4 achievements & 5 \\
Has 3 achievements & 4 \\
Has 2 achievements & 3 \\
Has 1 achievements & 2 \\
do not have & 1 \\
\hline
\end{tabular}

Tabel 7. Alternate Match Value

\begin{tabular}{lcccc}
\hline Alternative & C1 & C2 & C3 & C4 \\
\hline A1 & 3 & 5 & 2 & 1 \\
A2 & 5 & 4 & 1 & 3 \\
A3 & 3 & 5 & 2 & 1 \\
A4 & 4 & 5 & 2 & 2 \\
A5 & 4 & 4 & 1 & 1 \\
A6 & 3 & 2 & 3 & 4 \\
A7 & 5 & 2 & 1 & 1 \\
A8 & 4 & 3 & 1 & 3 \\
A9 & 3 & 3 & 1 & 3 \\
A10 & 3 & 4 & 2 & 2 \\
\hline
\end{tabular}

The alternative value of the suitability branch is taken from each alternative obtained from the research.

To solve the above problem using the PSI method, do the following steps:

1. There is an alternative table according to the value of each weight.

2. Find the minimum and maximum for each criterion.

Tabel 8. Alternative Max and Min

\begin{tabular}{|l|c|c|c|c|}
\hline \multicolumn{1}{|c|}{ Alternative } & C1 & C2 & C3 & C4 \\
\hline A1 & 3 & 5 & 2 & 1 \\
\hline A2 & 5 & 4 & 1 & 3 \\
\hline A3 & 3 & 5 & 2 & 1 \\
\hline A4 & 4 & 5 & 2 & 2 \\
\hline A5 & 4 & 4 & 1 & 1 \\
\hline A6 & 3 & 2 & 3 & 4 \\
\hline A7 & 5 & 2 & 1 & 1 \\
\hline
\end{tabular}

\begin{tabular}{|l|l|l|l|l|} 
A8 & 4 & 3 & 1 & 3 \\
\hline A9 & 3 & 3 & 1 & 3 \\
\hline A10 & 3 & 4 & 2 & 2 \\
\hline MAX & 5 & 5 & 3 & 4 \\
\hline MIN & 3 & 1 & 1 & 1 \\
\hline
\end{tabular}

3. Normalizing

$N i j=\frac{X i j}{X j \max }$

C1

$\begin{array}{ll}N 11=\frac{3}{5}=0,6 & N 61=\frac{3}{5}=0,6 \\ N 21=\frac{5}{5}=1 & N 71=\frac{5}{5}=1 \\ N 31=\frac{3}{5}=0,6 & N 81=\frac{4}{5}=0,8 \\ N 41=\frac{4}{5}=0,8 & N 101=\frac{3}{5}=0,6 \\ N 51=\frac{4}{5}=0,8 & N 62=\frac{2}{5}=0,4 \\ \mathrm{C} 2 & N 72=\frac{2}{5}=0,4 \\ N 12=\frac{5}{5}=1 & N 82=\frac{3}{5}=0,6 \\ N 22=\frac{4}{5}=0,8 & N 92=\frac{3}{5}=0,6 \\ N 32=\frac{5}{5}=1 & N 102=\frac{4}{5}=0,8 \\ N 42=\frac{5}{5}=1 & N\end{array}$

C3
$N 13=\frac{2}{3}=0,6667$
$N 63=\frac{3}{3}=1$
$N 23=\frac{1}{3}=0,3333$
$N 73=\frac{1}{3}=0,333$
$N 33=\frac{2}{3}=0,6667$
$N 83=\frac{1}{3}=0,333$
$N 43=\frac{2}{3}=0,6667$
$N 93=\frac{1}{3}=0,333$
$N 53=\frac{1}{3}=0,3333$
$N 103=\frac{2}{3}=0,6667$

C4

$N 14=\frac{1}{4}=0,25$

$N 64=\frac{4}{4}=1$

$N 24=\frac{3}{4}=0,75$

$N 74=\frac{1}{4}=0,25$

$N 34=\frac{1}{4}=0,25$

$N 84=\frac{3}{4}=0,75$

$N 44=\frac{2}{4}=0,5$ 
International Journal of Computer and Information System (IJCIS)

Peer Reviewed - International Journal

Vol : Vol. 03, Issue 01, January 2022

e-ISSN : 2745-9659

https://ijcis.net/index.php/ijcis/index

$$
N 54=\frac{1}{4}=0,25 \quad N 104=\frac{2}{4}=0,5
$$

From the sum of the calculations above, the result is $[7,4$, $7,4,5,333,5,25]$

4. Calculating the mean

$$
\begin{aligned}
& N=\frac{1}{n} \sum_{i=1}^{n} N i j=\frac{1}{10} \times 7,4=0,74 \\
& N=\frac{1}{n} \sum_{i=1}^{n} N i j=\frac{1}{10} \times 7,4=0,74 \\
& N=\frac{1}{n} \sum_{i=1}^{n} N i j=\frac{1}{10} \times 5,333=0,5333 \\
& N=\frac{1}{n} \sum_{i=1}^{n} N i j=\frac{1}{10} \times 5,25=0,525
\end{aligned}
$$

5. Determining the value of preference variation $\emptyset_{j}=$ $\sum_{i=1}^{n}[N i j-N]^{2}$

$\emptyset \mathbf{j 1}$

$\emptyset j 11=\sum n i(0,6-0.74) 2=0.0196$

$\emptyset j 21=\sum n i(1-0.74) 2=0.0676$

$\emptyset j 31=\sum n i(0,6-0.74) 2=0.0196$

$\emptyset j 41=\sum n i(0,8-0.74) 2=0.0036$

$\emptyset j 51=\sum n i(0.8-0.74) 2=0.0036$

$\emptyset j 61=\sum n i(0.6-0.74) 2=0.0196$

$\emptyset j 71=\sum n i(1-0.74) 2=0.0676$

$\emptyset j 81=\sum n i(0.8-0.74) 2=0.0036$

$\emptyset j 91=\sum n i(0.6-0.74) 2=0.0196$

$\emptyset j 101=\sum n i(0.6-0.74) 2=0.0196$

$\emptyset j 2$

$\emptyset j 12=\sum n i(1-0.74) 2=0.0676$

$\emptyset j 22=\sum n i(0.8-0.74) 2=0.0036$

$\emptyset j 32=\sum n i(1-0.74) 2=0.0676$

$\emptyset j 42=\sum n i(1-0.74) 2=0.0676$

$\emptyset j 52=\sum n i(0.8-0.74) 2=0.0036$

$\emptyset j 62=\sum n i(0.4-0.74) 2=0.1156$

$\emptyset j 72=\sum n i(0.4-0.74) 2=0.1156$

$\emptyset j 82=\sum n i(0.6-0.74) 2=0.0196$

$\emptyset j 92=\sum n i(0.6-0.74) 2=0.0196$

$\emptyset_{j 102}=\sum n i(0.8-0.74) 2=0.0036$

$\emptyset j 3$

$\emptyset j 13=\sum n i(0.6667-0.5333) 2=0.0178$

$\emptyset j 23=\sum n i(0.3333-0.5333) 2=0.04$

$\emptyset j 33=\sum n i(0.6667-0.5333) 2=0.0178$

$\emptyset j 43=\sum n i(0.6667-0.5333) 2=0.0178$

$\emptyset j 53=\sum n i(0.3333-0.5333) 2=0.04$

$\emptyset j 63=\sum n i(1-0.5333) 2=0.2178$

$\emptyset j 73=\sum n i(0.3333-0.5333) 2=0.04$

$\emptyset j 83=\sum n i(0.3333-0.5333) 2=0.04$

$\emptyset j 93=\sum n i(0.3333-0.5333) 2=0.04$

$\emptyset j 103=\sum n i(0.6667-0.5333) 2=0.0178$

$\emptyset j 4$

$\emptyset j 14=\sum n i(0.25-0.525) 2=0.0756$

$\emptyset j 24=\sum n i(0.75-0.525) 2=0.0506$

$\emptyset j 34=\sum n i(0.25-0.525) 2=0.0752$

$\emptyset j 44=\sum n i(0.5-0.525) 2=0.0006$

$\emptyset j 54=\sum n i(0.25-0.525) 2=0.0756$

$\emptyset j 64=\sum n i(0.1-0.525) 2=0.2256$

$\emptyset j 74=\sum n i(0,25-0.525) 2=0.0756$

$\emptyset j 84=\sum n i(0.75-0.525) 2=0.0506$

$\emptyset j 94=\sum n i(0.75-0.525) 2=0.0506$

$\emptyset j 104=\sum n i(0.5-0.525) 2=0.0006$
The result of the sum of the preference variations is [0.244, $0.484,0.4889,06813$ ]

6. Specifying the value in preferences

$$
\begin{aligned}
& \Omega j=1-\Phi j \\
& \Omega 1=1-0.244=0.756 \\
& \Omega 2=1-0.484=0.516 \\
& \Omega 3=1-0.4889=0.5111 \\
& \Omega 4=1-0.6813=0.3188 \\
& \sum \Omega j=0.756+0.516+0.5111+0.3188=2,1026
\end{aligned}
$$

7. Determine the weight criteria:

$$
\begin{aligned}
W j & =\frac{\Omega \mathrm{j}}{\sum_{j=1}^{m} \Omega \mathrm{j}} \\
W j & =\frac{\Omega \mathrm{j}}{\sum_{j=1}^{m} \Omega \mathrm{j}}=\frac{0.756}{2,1026}=0.3597 \\
W j & =\frac{\Omega \mathrm{j}}{\sum_{j=1}^{m} \Omega \mathrm{j}}=\frac{0.516}{2,1026}=0.2455 \\
W j & =\frac{\Omega \mathrm{j}}{\sum_{j=1}^{m} \Omega \mathrm{j}}=\frac{0.5111}{2,1026}=0.2432 \\
W j & =\frac{\Omega \mathrm{j}}{\sum_{j=1}^{m} \Omega \mathrm{j}}=\frac{0.3188}{2,1026}=0.1517 \\
W j & =[0.3597,0.2455,0.2432,0.1517]
\end{aligned}
$$

8. Count PSI

$$
\begin{aligned}
& \emptyset i=\sum_{j=1}^{m} X i j \times W j \\
& \theta 1 \\
& \theta 1=0.6 \times 0.3597=0.2158 \\
& \theta 1=1 \times 0.3597=0.3597 \\
& \theta 1=0.6 \times 0.3597=0.2158 \\
& \theta 1=0.8 \times 0.3597=0.2877 \\
& \theta 1=0.8 \times 0.3597=0.2877 \\
& \theta 1=0.6 \times 0.3597=0.2158 \\
& \theta 1=1 \times 0.3597=0.3597 \\
& \theta 1=0.8 \times 0.3597=0.2877 \\
& \theta 1=0.6 \times 0.3597=0.2158 \\
& \theta 1=0.6 \times 0.3597=0.2158 \\
& \theta 2 \\
& \theta 2=1 \times 0.2455=0.2455 \\
& \theta 2=0.8 \times 0.2455=0.1964 \\
& \theta 2=1 \times 0.2455=0.2455 \\
& \theta 2=1 \times 0.2455=0.2455 \\
& \theta 2=0.8 \times 0.2455=0.1964 \\
& \theta 2=0.4 \times 0.2455=0.0982 \\
& \theta 2=0.4 \times 0.0 .2455=0.0982 \\
& \theta 2=0.6 \times 0.2455=0.1473 \\
& \theta 2=0.6 \times 0.2455=0.1473 \\
& \theta 2=0.8 \times 0.2455=0.1964 \\
& \theta 3=0.6667 \times 0.2432=0.1621 \\
& \theta 3=0.3333 \times 0.2432=0.0811 \\
& \theta 3=0.6667 \times 0.2432=0.1621 \\
& \theta 3=0.6667 \times 0.2432=0.1621 \\
& \theta 3=0.3333 \times 0.2432=0.0811 \\
& \theta 3=1 \times 0.2432=0.2432 \\
& \theta 3
\end{aligned}
$$


International Journal of Computer and Information System (IJCIS)

Peer Reviewed - International Journal

Vol : Vol. 03, Issue 01, January 2022

e-ISSN : 2745-9659

https://ijcis.net/index.php/ijcis/index

$\theta 3=0.3333 \times 0.2432=0.0811$
$\theta 3=0.3333 \times 0.2432=0.0811$
$\theta 3=0.3333 \times 0.2432=0.0811$
$\theta 3=0.6667 \times 0.2432=0.1621$

$\theta 4$

$\theta 4=0.25 \times 0.1517=0.0379$

$\theta 4=0.75 \times 0.1517=0.1137$

$\theta 4=0.25 \times 0.1517=0.0379$

$\theta 4=0.5 \times 0.1517=0.0758$

$\theta 4=0.25 \times 0.1517=0.0379$

$\theta 4=1 \times 0.1517=0.1517$

$\theta 4=0.25 \times 0.1517=0.0379$

$\theta 4=0.75 \times 0.1517=0.1137$

$\theta 4=0.75 \times 0.1517=0.1137$

$\theta 4=0.5 \times 0.1517=0.0758$

9. Looking for ranking value

$$
\begin{aligned}
& A 1=0.2158+0.2455+0.1621+0.0379=0.6613 \\
& A 2=0.3597+0.1964+0.0811+0.1137=0.7509 \\
& A 3=0.2158+0.2455+0.1621+0.0379=0.6613 \\
& A 4=0.2877+0.2455+0.1621+0.0758=0.7712 \\
& A 5=0.2877+0.1964+0.0811+0.0379=0.6031 \\
& A 6=0.2158+0.0982+0.2432+0.1517=0.7088 \\
& A 7=0.3597+0.0982+0.0811+0.0379=0.5768 \\
& A 8=0.2877+0.1473+0.0811+0.1137=0.6298 \\
& A 9=0.2158+0.1473+0.0811+0.1137=0.5579 \\
& A 10=0.2158+0.1962+0.1621+0.0758 \\
& =0.6501
\end{aligned}
$$

After calculating the PSI (Qi) assessment, a ranking is carried out to get prospective scholarship recipients, ranking from the highest total from the sum of the PSI scores. The ranking results are as follows:

Tabel 9. Ranking Results

\begin{tabular}{lllcl} 
Alternatif & Keterangan & Nilai & Ranking & [6] \\
\cline { 1 - 4 } A1 & IKE NURJANAH & 0,6613 & 4 & \\
A2 & INNAYATUN MUSTAFIDA & 0,7509 & 2 & \\
A3 & FARIDATUS SANIYAH & 0,6613 & 4 & \\
A4 & ALDEA MULIA SINAI & 0,7712 & 1 & [7] \\
A5 & EVA FATHURROHMAH & 0,6031 & 8 & [8] \\
A6 & ARIN ALFA SAIDA & 0,7088 & 3 & \\
A7 & ADELIA SOFIA ANJANI & 0,5768 & 9 & \\
A8 & AMALIA NUR HIDAYATI & 0,6298 & 7 & [9] \\
A9 & ELA UMAYAH & 0,5579 & 10 & \\
A10 & FATIMAH & 0.6501 & 6 & \\
\cline { 1 - 3 }
\end{tabular}

\section{CONCLUSION}

The PSI (Preference Selection Index) method can be used in the decision-making system for selecting student scholarships, in its calculation the PSI method is able to produce weights that will be used to find the best alternative.
In the calculations that have been carried out, it is found that alternative A4 on behalf of Aldea Mulia Sinai is the chosen alternative because it has the highest final preference index value. So you are eligible for a scholarship.

The existence of a decision support system on scholarships will help the recipients of scholarships in making decisions because it is felt that the system can increase the effectiveness and efficiency of decision making. Decision support systems are more efficient in processing calculations for scholarship receipts compared to manuals because of computerization The best alternative generation results were obtained by Aldea Mulia Sinai with a value of 0.7712 .

\section{REFERENCES}

E. Murniasih, Buku Pintar Beasiswa. Jakarta: Gagas Media, 2009.

Y. Irawan, "Sistem Pendukung Keputusan Penentuan Penerimaan Beasiswa Berbasis Web Sma Islam Darul Huda Menggunakan Metode Analytical Hierarchy Process (Ahp)," J. Ilmu Komput., vol. 7, no. 1, pp. 1-6, 2018, doi: 10.33060/jik/2018/vol7.iss1.74.

M. Riadi, "Sistem Pendukung Keputusan (SPK)," 2013. https://www.kajianpustaka.com/2013/09/sistem-

pendukung-keputusan-spk.html (accessed Mar. 17, 2021). F. Syahputra, M. Mesran, I. Lubis, and A. P. Windarto, "Sistem Pendukung Keputusan Pemilihan Guru Berprestasi Kota Medan Menerapkan Metode Preferences Selection Index (Studi Kasus: Dinas Pendidikan Kota Medan)," KOMIK (Konferensi Nas. Teknol. Inf. dan Komputer), vol. 2, no. 1, pp. 147-155, 2018, doi: 10.30865/komik.v2i1.921.

N. P. Rizanti, L. T. Sianturi, and M. Sianturi, "Sistem Pendukung Keputusan Pemilihan Siswa Pertukaran Pelajar Menggunakan Metode PSI (Preference Selection Index)," Semin. Nas. Teknol. Komput. dan Sains, pp. 263-269, 2019, [Online]. Available: http://seminarid.com/prosiding/index.php/sainteks/article/view/165/166

R. Attri and S. Grover, "Application of preference selection index method for decision making over the design stage of production system life cycle," J. King Saud Univ. - Eng. Sci., vol. 27, no. 2, pp. 207-216, 2015, doi: 10.1016/j.jksues.2013.06.003.

Sugiyono, METODE PENELITIAN KUANTITATIF, KUALITATIF dan R\&D. Bandung: Alfabeta, 2009.

D. ambar Wasesha, "IMPLEMENTASI MODEL WATERFALL DALAM SISTEM PENDUKUNG KEPUTUSAN PENYEDIA INFORMASI AKADEMIK UNIVERSITAS," vol. 14, no. 1, pp. 41-48, 2019.

R. Panggabean and N. A. Hasibuan, "Penerapan Preference Selection Index ( PSI ) Dalam Sistem Pendukung Keputusan Pengangkatan Supervisor Housekeeping," Rekayasa Tek. Inform. dan Inf., vol. 1, no. 2, pp. 85-93, 2020

Sundari, S., Fadli, M. N., Hartama, D., Windarto, A. P., \& Wanto, A. (2019, August). Decision Support System on Selection of Lecturer Research Grant Proposals using Preferences Selection Index. In Journal of Physics: Conference Series (Vol. 1255, No. 1, p. 012006). IOP Publishing. 